\title{
TINGKAT KEPUASAN PARKIR KAMPUS ANGGREK BINUS UNIVERSITY DITINJAU DARI FASILITAS GEOMETRI DAN SURVEI KEPUASAN PARKIR
}

\author{
Irpan Hidayat \\ Civil Engineering Department, Faculty of Engineering, Binus University \\ Jl. K.H. Syahdan No. 9, Palmerah, Jakarta Barat 11480 \\ irpan@binus.edu
}

\begin{abstract}
Evaluated from the level of saturation, Anggrek Campus Binus University facilities are considerably able to accommodate all vehicles to park. However, from observations over the years, even though the capacity still seems able to accommodate, there are still some drivers who have difficulty in placing their vehicle in the provided parking lots. In results, it take a long time for drivers to do the maneuvers. Due to this reason, there is a need to review the geometric conditions of a parking space and user parking satisfaction at Anggrek Campus. The research method is to conduct a survei for the parking geometry in a questionnaire form, which aims to determine the satisfaction level of the parking facility from the user side. The research results acquired for parking plot $4000 \times 2400 \mathrm{~mm}$, the type of vehicles that meet the requirements of free space to park in the lateral direction of the plot is city car, jeep, and MPV. As for the parking plot $5000 \times 3000 \mathrm{~mm}$, free parking space requirements for the lateral direction meet for all types of vehicles (city car, jeeps, MPV, sedans, and SUVs). Results stated that $39 \%$ of respondents are comfortable in terms of ease of parking, $37 \%$ of respondents express comfort in opening the car door after parking their vehicle, 24\% said parking signs are very useful for them in getting the parking information. However, 22\% of respondents expressed their discomfort in the ease of parking due to the geometry of $90^{\circ}$ parking pattern.
\end{abstract}

Keywords: parking, geometry parking, Anggrek Campus

\begin{abstract}
ABSTRAK
Dari hasil pengamatan selama ini, dengan daya tampung yang cukup baik masih terlihat beberapa pengemudi mengalami kesulitan dalam menempatkan kendaraannya pada petak-petak parkir yang telah disediakan di Kampus Anggrek Binus University. Hal ini menyebabkan manuver pengemudi kendaraan membutuhkan waktu yang cukup lama. Untuk itu, perlu tinjauan mengenai kondisi geometrik dari ruang parkir dan kepuasan pengguna yang ada pada parkir Kampus Anggrek. Metode penelitian yang dilakukan adalah melakukan survei geometri parkir berdasarkan Pedoman Perencanaan dan Pengoperasian Fasilitas Parkir (1998). Dari hasil survei geometri, dibuatkanlah pertanyaan-pertanyaan dalam bentuk kuisioner, yang bertujuan untuk mengetahui tingkat kepuasan fasilitas parkir dari sisi pengguna. Dari hasil penelitian diperoleh bahwa, untuk petak parkir $4000 \times 2400 \mathrm{~mm}$, jenis kendaraan yang memenuhi persyaratan ruang bebas melakukan parkir arah lateral di petak tersebut adalah city car, jeep, dan MPV. Sedangkan untuk petak parkir dimensi 5000 × 3000 mm, persyaratan ruang bebas parkir untuk arah lateral terpenuhi untuk semua jenis kendaraan (city car, jeep, MPV, sedan, dan SUV). Didapat $39 \%$ responden menyatakan nyaman dalam hal kemudahan parkir, $37 \%$ responden menyatakan nyaman dalam membuka pintu mobil setelah memarkirkan kendaraannya, $24 \%$ menyatakan rambu-rambu parkir membantu mereka dalam mendapatkan informasi parkir gedung. Akan tetapi, 22 \% responden menyatakan ketidaknyamanannya dalam kemudahan parkir yang disebabkan geometri pola parkir yang membentuk sudut $90^{\circ}$.
\end{abstract}

Kata kunci: parkir, geometri parkir, Kampus Anggrek 


\section{PENDAHULUAN}

Ditinjau dari tingkat kejenuhan, fasilitas Kampus Anggrek Binus University sudahmampumenampungkendaraan yang akan parkir di area parkir. Terlihat dari penelitian sebelumnya dengan” Studi Parkir Kampus Anggrek Kondisi Eksisting dan Penambahan Lahan Parkir Baru Terhadap Pengguna Kampus Anggrek Binus University” (Hidayat, 2009), yang mendapatkan hasil bahwa penambahan ruang parkir meningkatkan daya tamping parkir gedung Kampus Anggrek. Akan tetapi, dari hasil pemantauan selama ini dengan daya tampung yang cukup baik masih terlihat beberapa pengemudi mengalami kesulitan dalam menempatkan kendaraannya pada petak-petak parkir yang telah disediakan. Hal ini menyebabkan waktu maneuver pengemudi kendaraan roda empat (mobil pribadi) membutuhkan waktu yang cukup lama. Untuk itu, perlu tinjauan mengenai kondisi geometric dari ruang parkir yang ada pada lingkungan Kampus Anggrek. Tinjauan dapat berupa melakukan survei mengenai geometri, petak parkir yang ada apakah sudah sesuai dengan standar parkir, dan dilakukan penyebaran kuisioner kepada pengguna lahan parkir sehingga dihasilkan sampelsampel data mengenai kepuasan pengguna dalam melakukan aktivitas parkir di lingkungan Kampus Anggrek Binus University.

Untuk mengetahui tingkat kepuasan dari pengguna, dilakukan survei geometri dengan menggunakan alat ukur tanah seperti teodolit, waterpass, meteran, counter, stopwatch, dan tripod. Hasil pengukuran berupa sudut parkir, lebar akses parkir, ruang bebas kendaraan parkir, dan lebar bukaan pintu kendaraan. Kemudian dengan hasil data pengukuran tersebut di cek apakah geometri parkir sudah sesuai dengan standar. Nilai geometri ini akan dibandingkan ataupun menjadi referensi dalam pembuatan kuisioner kepuasan pengguna parkir. Porsentase kepuasan pengguna fasilitas parkir akan diperoleh apabila pengguna menyatakan ataupun menginformasikan bahwa ruang parkir tersedia, fasilitas pelengkapnya, dan kemudahan mendapatkan parkir terpenuhi. Untuk mendapatkan informasiinformasi tersebut akan dilakukan penyebaran kuisioner di mana isi kuisioner secara umum adalah mengenai apakah fasilitas parkir Kampus Anggrek sudah sesuai, kemudahan mendapatkan parkir, sudut parkir yang ada membuat anda kesulitan dalam memarkirkan kendaraan, lamanya anda mendapatkan tempat parkir dan lokasi parkir yang anda senangi.

Tujuan dari penelitian ini adalah sebagai berikut: (1) mengetahui tingkat kepuasan pengguna parker dari segi fasilitas geometri parker seperti petak parkir, sudut parkir, ruang bebas parker; (2) menghitung persentase kepuasan parkir dari sisi pengguna parkir; (3) menganalisis apakah sistem parkir yang ada sudah memenuhi kriteria standar perencanaan dan mendapatkan respons yang baik dari penggunanya.

\section{METODE}

Langkah awal yang dilakukan adalah meninjau sekaligus merumuskan masalah yang ada pada area Kampus Anggrek Binus University. Kemudian mencari referensi buku-buku dan jurnal ilmiah yang terkait dengan topik tingkat kepuasan parkir. Dilanjutkan dengan melakukan survei lapangan mengenai petak parkir, sudut parkir, lebar akses parkir, ruang bebas kendaraan parkir, lebar bukaan pintu kendaraan, dan fasilitas parkir lainya. Lalu merencanakan target responden yang diberikan kuisioner mengenai tingkat kepuasan pengguna. Setelah data geometri parkir dan kuisioner terkumpul, dilakukan analisis untuk dibuat hasil kesimpulan penelitian ini. Metode penelitian dilakukan seperti gambar diagram alir di bawah ini (Gambar 1). 


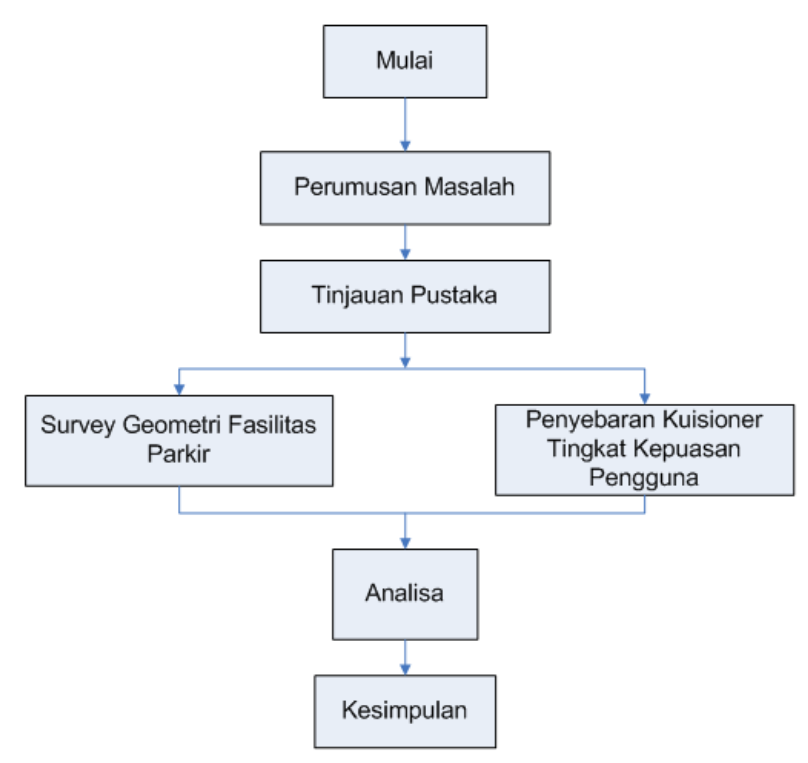

Gambar 1 Diagram alir penelitian

\section{HASIL DAN PEMBAHASAN}

\section{Lokasi Segmen Lahan Parkir}

Lokasi lahan parkir kampus anggrek yang di survei pada penelitian ini dibagi menjadi beberapa bagian, yaitu segmen 1, 2, 3, 4, 5, lantai 1A, 1B, 2A, 2B, 3A, 3B, 4A, 4B, 5A, 5B, 6A, 6B, 7A, 7B, 8A, dan 8B. Pembagian ini dimaksudkan untuk mempermudah tim surveior dalam mengamati dan mencatat pola parkir dari tiap segmen. Gambar di bawah ini adalah hasil pemetaan parkir dari tiap segmen (Gambar 2 - 4).

\section{Pemeriksaan Geometri Parkir}

Jenis pemeriksaan geometri parkir pada penelitian ini dibagi menjadi tiga jenis pemeriksaan yaitu ukuran kebutuhan ruang parkir, desain parkir di badan jalan, dan desain parkir di luar badan jalan. Dari ketiga jenis pemeriksaan tersebut di definisikan lebih khusus menjadi satuan ruang parkir, sudut parkir, pola parkir, jalur sirkulasi, gang, jalan masuk dan keluar parkir. Tabel 1 memberikan gambaran jenis pemeriksaan, detail pemeriksaan dan hasil pengamatan geometri parkir.

\section{Perhitungan Ruang Bebas Kendaraan}

Perhitungan satuan ruang bebas kendaraan parkir berdasarkan Pedoman Perencanaan dan Pengoperasian Fasilitas Parkir (Direktorat Jenderal Perhubungan Darat, 1998). Jika dirangkumkan, rumusan untuk ruang bebas kendaraan parkir arah lateral dan arah longitudinal adalah sebagai berikut:

Arah lateral $: \mathrm{Rx}=\mathrm{Bp}-\mathrm{B}-\mathrm{O}$

Arah longitudinal $\quad: \mathrm{Ry}=\mathrm{R}=\mathrm{Lp}-\mathrm{L}-\mathrm{a} 1-\mathrm{a} 2$ keterangan:

$\mathrm{Bp}=$ lebar slot parkir

$\mathrm{B}=$ lebar total kendaraan

Lp = panjang slot parkir

$\mathrm{O}=$ lebarbukaanpintu

$\mathrm{L}=$ panjang total kendaraan

$\mathrm{R}=$ jarak bebas kendaraan

a1, a2 = jarak bebas arah longitudinal 
Perbandingan nilai a1 dan a2 dapat diambil sebagai perbandingan 1: 2 dalam ukuran dimensi panjang (Tabel 2 dan 3)..
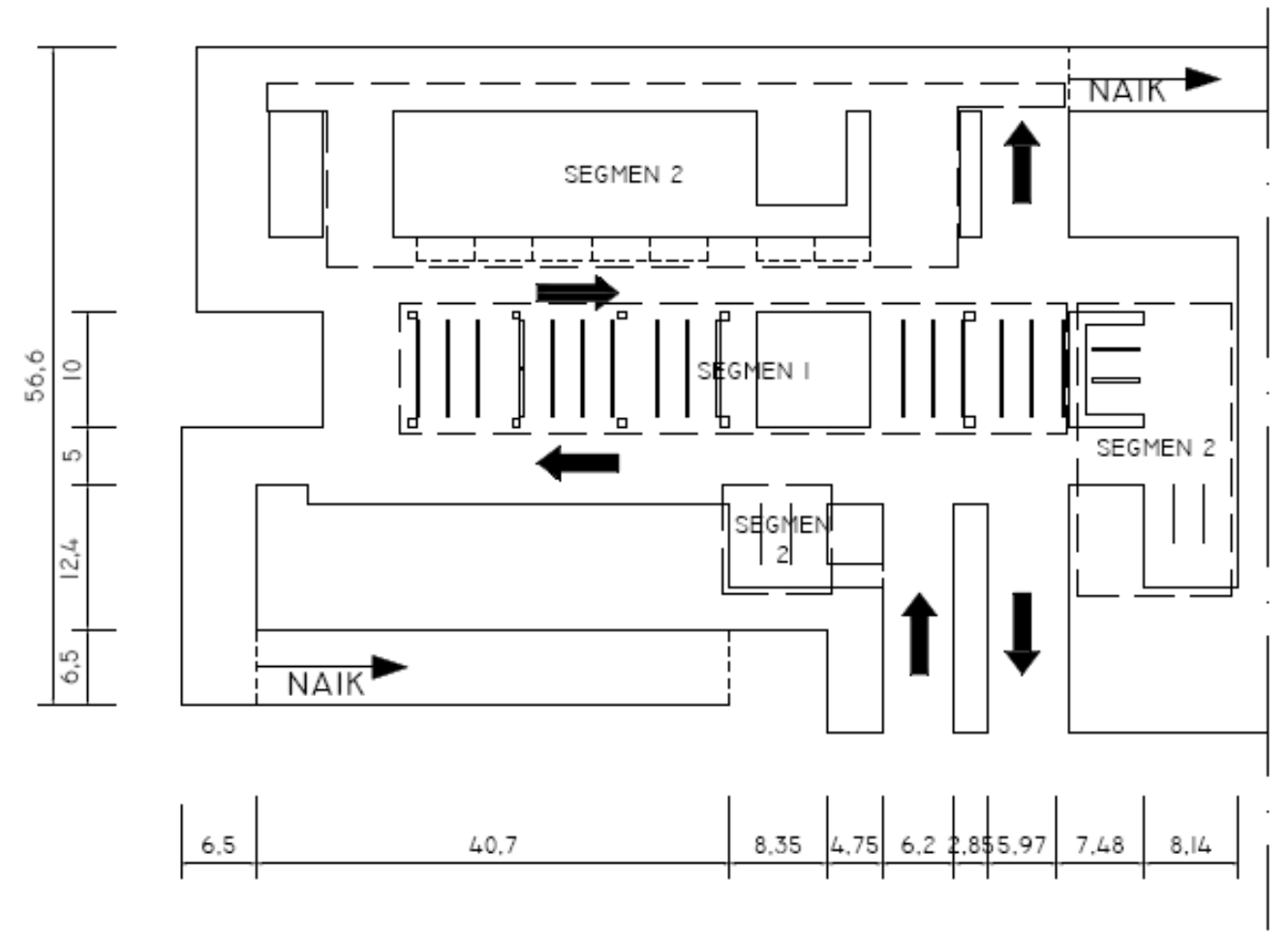

Gambar 2 Pemetaan parkir segmen 1 dan 2

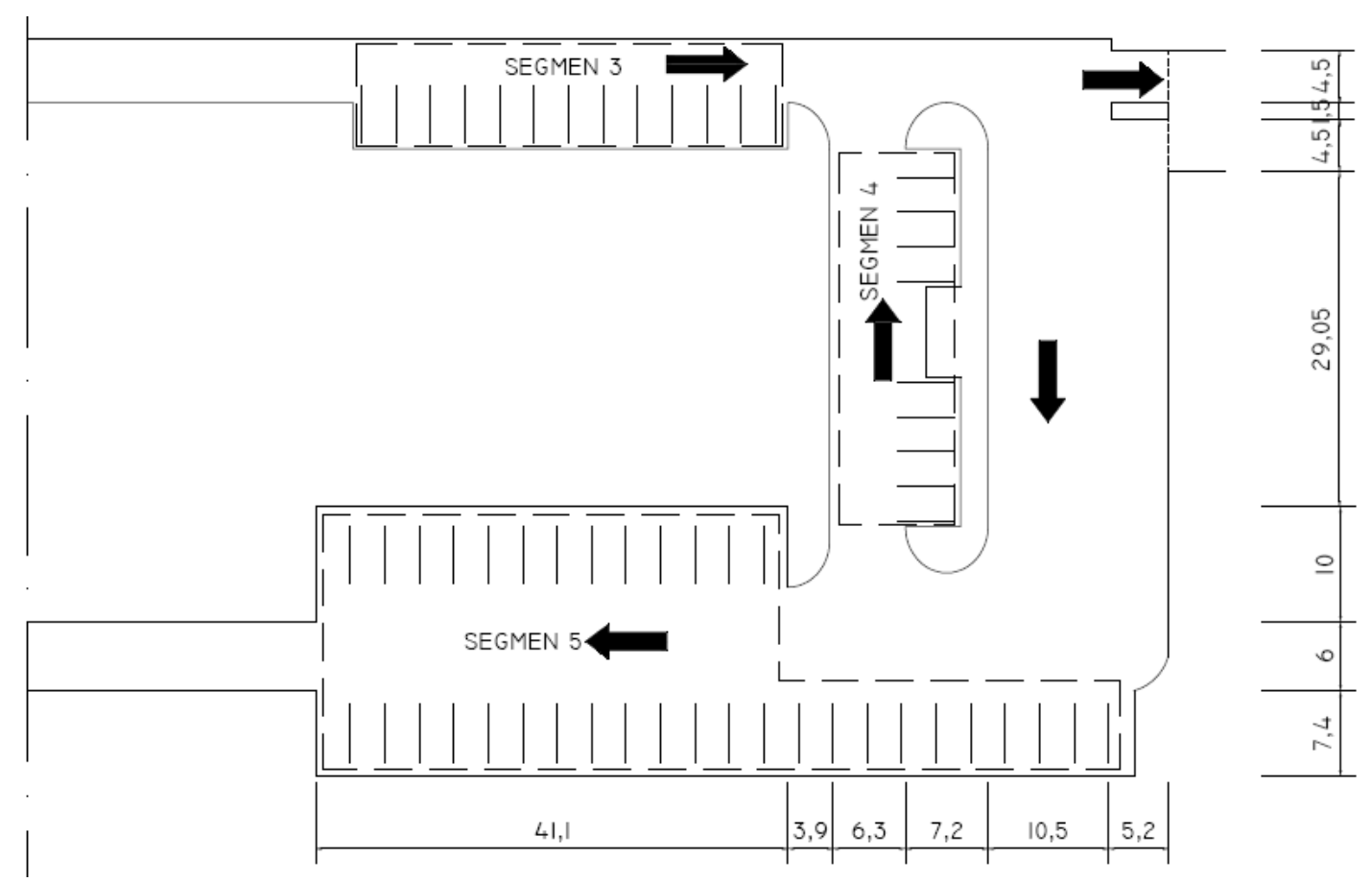

Gambar 3 Pemetaan parkir segmen 3, 4, dan 5 


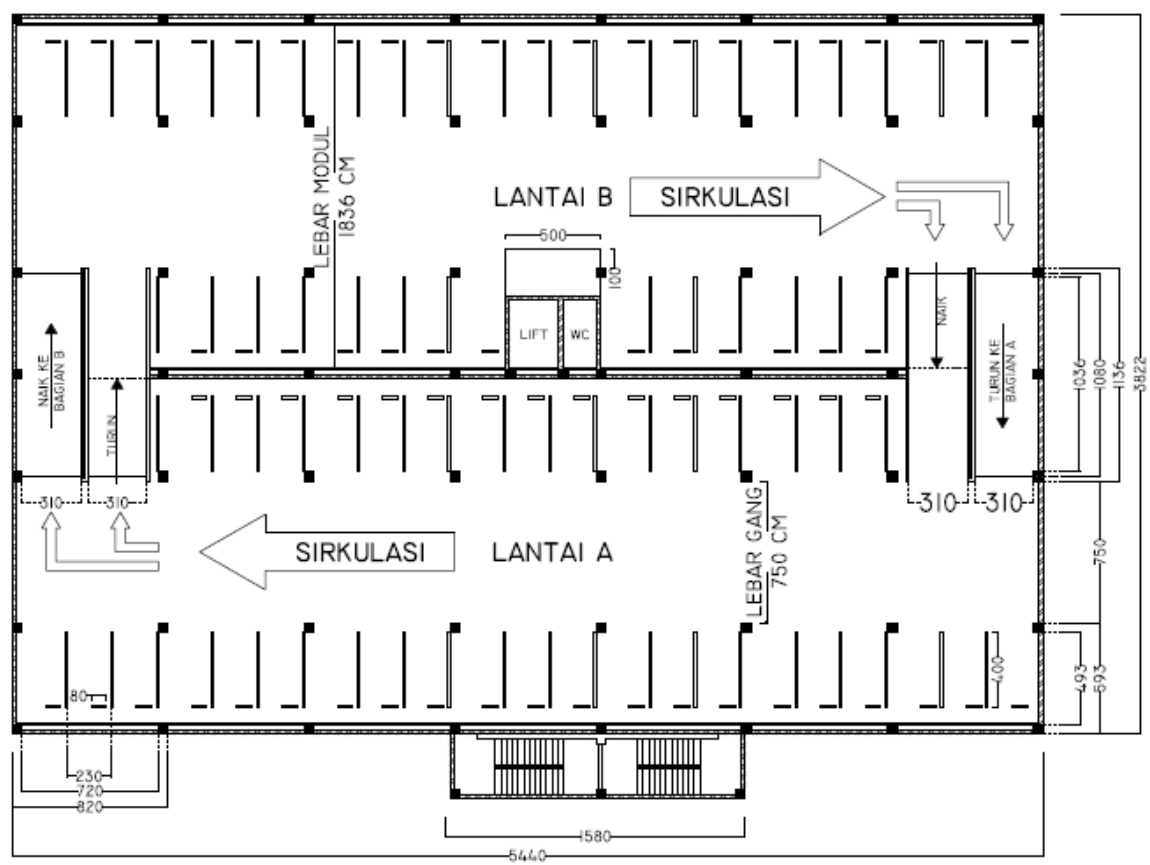

Gambar 4 Pemetaan parkir bagian A dan B setiap lantai gedung parkir

Tabel 1 Pemeriksaan Geometri Parkir Kampus Anggrek Binus University

\begin{tabular}{|c|c|c|}
\hline No & Jenis pemeriksaan & Detail pemeriksaan \\
\hline 1 & $\begin{array}{l}\text { Ukuran kebutuhan ruang } \\
\text { parkir }\end{array}$ & $\begin{array}{ll}\text { satuan ruang parkir: } \\
\text { • } & \text { Dimensi kendaraan standar untuk mobil penumpang } \\
\text { • } & \text { Ruang bebas kendaraan parkir }\end{array}$ \\
\hline \multirow[t]{2}{*}{2} & Desain parkir di badan jalan & $\begin{array}{l}\text { penentuan sudut parkir: } \\
\text { - } \quad \text { Lebar jalan } \\
\text { - } \text { Volume lalu lintas jalan yang bersangkutan } \\
\text { - } \quad \text { Karakterisitik kendaraan } \\
\text { - } \quad \text { Simensi kendaraan peruntukkan lahan sekitarnya dan peranan jalan yang } \\
\text { bersangkutan }\end{array}$ \\
\hline & & $\begin{array}{l}\text { pola parkir: } \\
\text { • } \quad \text { Pola parkir paralel (daerah datar, tanjakan, turunan) } \\
\text { - } \quad \text { Pola parkir menyudut }\end{array}$ \\
\hline \multirow[t]{3}{*}{3} & $\begin{array}{l}\text { Desain parkir di luar badan } \\
\text { jalan (gedung) }\end{array}$ & $\begin{array}{cl}\text { kriteria pola parkir mobil penumpang: } \\
\text { - } \quad \text { Parkir kendaraan satu sisi } \\
\text { - } \quad \text { Parkir kendaraan dua sisi } \\
\text { - } & \text { Pola parkir pulau } \\
\end{array}$ \\
\hline & & $\begin{array}{ll}\text { jalur sirkulasi, gang, dan modul: } \\
\text { - } & \text { Panjang jalur gang } \\
\text { - } & \text { Jalur sirkulasi } \\
\text { - } & \text { Lebar gang }\end{array}$ \\
\hline & & $\begin{array}{c}\text { Tata letak gedung parkir dapat diklasifikasikan sebagai berikut: } \\
\text { - } \quad \text { Lantai datar dengan jalur landai luar (external ramp) } \\
\text { - } \quad \text { Lantai terpisah } \\
\text { - } \quad \text { Lantai gedung yang berfungsi sebagai ramp } \\
\text { - } \quad \text { Tinggi minimal ruang bebas lantai gedung parkir adalah }\end{array}$ \\
\hline
\end{tabular}




\begin{tabular}{ll}
\hline & $2,5 \mathrm{~m}$. \\
\cline { 2 - 3 } & Jalan masuk dan keluar parkir: \\
$\bullet$ & Pintu masuk dan keluar terpisah \\
& Pintu masuk dan keluar satu \\
\hline Pemeliharaan parkir: \\
$\bullet \quad$ Pelataran parkir \\
$\bullet \quad$ Marka dan rambu jalan \\
$\bullet \quad$ Fasilitas penunjang parkir \\
\hline
\end{tabular}

Tabel 2 Persyaratan Ruang Bebas Kendaraan Petak Parkir 4000 x 2400 mm

\begin{tabular}{|c|c|c|c|c|c|c|c|c|c|c|c|}
\hline \multirow{2}{*}{$\begin{array}{c}\text { Tipe } \\
\text { Kendaraan }\end{array}$} & \multirow{2}{*}{$\begin{array}{c}\mathbf{L} \\
\mathbf{m m}\end{array}$} & \multirow{2}{*}{$\begin{array}{c}\text { B } \\
\mathbf{m m}\end{array}$} & \multicolumn{2}{|c|}{ Slot Parkir } & \multirow{2}{*}{$\begin{array}{c}\mathbf{O} \\
\mathbf{m m}\end{array}$} & \multirow{2}{*}{$\begin{array}{c}\mathbf{R} \\
\mathbf{m m}\end{array}$} & \multicolumn{2}{|c|}{$\begin{array}{c}\text { Jarak Bebas } \\
\text { Arah } \\
\text { Longitudinal }\end{array}$} & \multicolumn{2}{|c|}{$\begin{array}{c}\text { Persyaratan Ruang } \\
\text { Bebas }\end{array}$} & \multirow[t]{2}{*}{ Keterangan } \\
\hline & & & $\begin{array}{r}\text { Lp } \\
\mathbf{m m}\end{array}$ & $\begin{array}{r}\text { Bp } \\
\mathbf{m m}\end{array}$ & & & $\begin{array}{c}\mathbf{a 1} \\
\mathbf{m m}\end{array}$ & $\begin{array}{c}\text { a2 } \\
\mathbf{m m}\end{array}$ & $\begin{array}{c}\text { Arah } \\
\text { Lateral }\end{array}$ & $\begin{array}{c}\text { Arah } \\
\text { Longitudinal }\end{array}$ & \\
\hline City car & 3900 & 1695 & 4000 & 2400 & 550 & 155 & 33,3 & 66,7 & $>50 \mathrm{~mm}$ & $>300 \mathrm{~mm}$ & $\begin{array}{l}\text { Lateral ok, } \\
\text { longitudinal } \\
\text { tidak ok }\end{array}$ \\
\hline Jeep & 3430 & 1460 & 4000 & 2400 & 550 & 390 & 190 & 380 & $>50 \mathrm{~mm}$ & > $300 \mathrm{~mm}$ & $\begin{array}{l}\text { Lateral ok, } \\
\text { longitudinal } \\
\text { tidak ok } \\
\end{array}$ \\
\hline MPV & 4580 & 1770 & 4000 & 2400 & 550 & 80 & 0 & 0 & $>50 \mathrm{~mm}$ & $>300 \mathrm{~mm}$ & $\begin{array}{l}\text { Lateral ok, } \\
\text { longitudinal } \\
\text { tidak ok } \\
\end{array}$ \\
\hline Sedan & 4825 & 1820 & 4000 & 2400 & 550 & 30 & 0 & 0 & $>50 \mathrm{~mm}$ & $>300 \mathrm{~mm}$ & $\begin{array}{l}\text { Lateral tidak } \\
\text { ok, } \\
\text { longitudinal } \\
\text { tidak ok }\end{array}$ \\
\hline SUV & 4695 & 1840 & 4000 & 2400 & 550 & 10 & 0 & 0 & $>50 \mathrm{~mm}$ & $>300 \mathrm{~mm}$ & $\begin{array}{l}\text { Lateral tidak } \\
\text { ok, } \\
\text { longitudinal } \\
\text { tidak ok }\end{array}$ \\
\hline
\end{tabular}

Tabel 3 Persyaratan Ruang Bebas Kendaraan Petak Parkir 5000 x 3000 mm

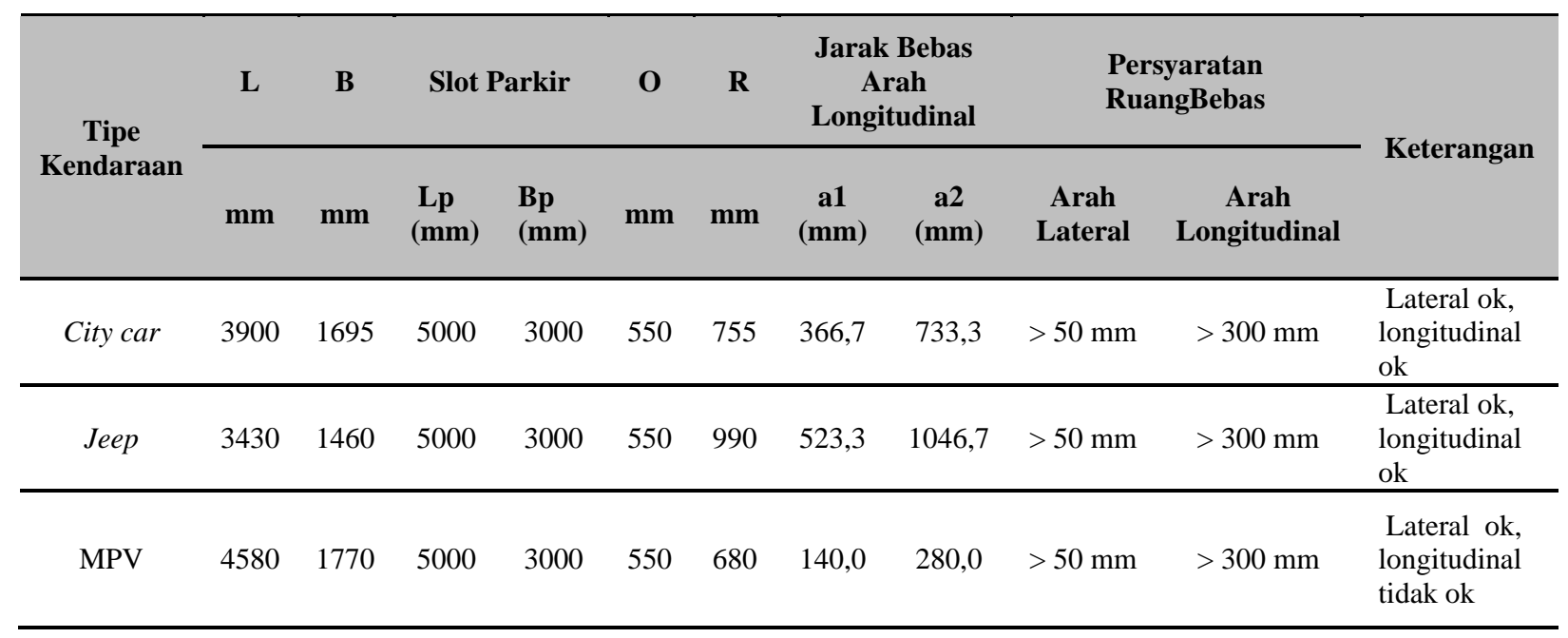




\begin{tabular}{cccccccccccc}
\hline Sedan & 4825 & 1820 & 5000 & 3000 & 550 & 630 & 58,3 & 116,7 & $>50 \mathrm{~mm}$ & $>300 \mathrm{~mm}$ & $\begin{array}{c}\text { Lateral ok, } \\
\text { longitudinal } \\
\text { tidak ok }\end{array}$ \\
\hline SUV & 4695 & 1840 & 5000 & 3000 & 550 & 610 & 101,7 & 203,3 & $>50 \mathrm{~mm}$ & $>300 \mathrm{~mm}$ & $\begin{array}{c}\text { Lateral ok, } \\
\text { longitudinal } \\
\text { tidak ok }\end{array}$ \\
\hline
\end{tabular}

Dari hasil tabel 2 dan tabel 3 di atas diperoleh bahwa, dengan petak parkir dimensi $4000 \mathrm{x}$ $2400 \mathrm{~mm}$, jenis kendaraan yang memenuhi persyaratan ruang bebas melakukan parkir arah lateral di petak tersebut adalah city car, jeep, dan MPV. Sedangkan untuk arah longitudinal di petak parkir dimensi 4000 x $2400 \mathrm{~mm}$, tidak satu pun jenis kendaraan memenuhi persyaratan ruang bebas parkir. Untuk petak parkir dimensi 5000 × $3000 \mathrm{~m}$, persyaratan ruang bebas parkir untuk arah lateral terpenuhi untuk semua jenis kendaraan. Sedangkan untuk arah longitudinalnya, hanya jenis kendaraan city car, jeep, dan MPV yang memenuhi persyaratan ruang beban kendaraan arah longitudinal.

\section{Desain Parkir di Luar Badan Jalan}

\section{Pola Parkir}

Pola parkir yang ada di lahan parkir Kampus Anggrek adalah parkir kendaraan satu sisi dan parkir kendaraan dua sisi. Dimana kedua pola parkir tersebut membentuk sudut $90^{\circ}$.

\section{Jalur Sirkulasi, Gang, dan Modul}

Perbedaan antara jalur sirkulasi dan jalur gang terutama terletak pada penggunaannya.

Patokan umum yang dipakai adalah: (1) panjang sebuah jalur gang tidak lebih dari 100 meter; (2) jalur gang yang ini dimaksudkan untuk melayani lebih dari 50 kendaraan dianggap sebagai jalur sirkulasi.

Segmen 1 sampai dengan segmen 5 didefinisikan sebagai jalur gang karena menampung kurang dari 50 kendaraan. Jalur sirkulasi parkir kampus anggrek adalah satu arah di semua area sirkulasi parkir (segmen dan lantai parkir). Ukuran dari jalur sirkulasi dan modul parkir pada kampus anggrek lantai 1 sampai dengan lantai 8 seperti di tunjukkan pada Tabel 4

Tabel 4 Pemeriksaan Jalur Sirkulasi, Gang, Modul

\begin{tabular}{llccc}
\hline No & Pemeriksaan & $\begin{array}{c}\text { Pengamatan di } \\
\text { Lapangan }(\mathbf{m})\end{array}$ & $\begin{array}{c}\text { Nilai Batas } \\
(\mathbf{m})\end{array}$ & Keterangan \\
\hline 1 & Jalur sirkulasi satu arah & 7,5 & 3,5 & ok \\
\hline 2 & Modul & 18,36 & - & - \\
\hline
\end{tabular}

Dari tabel 4 di atas, dapat dinyatakan bahwa lebar jalur sirkulasi parkir sudah memenuhi batas yang ditetapkan dalam Pedoman Perencanaan dan Pengoperasian Fasilitas Parkir (Direktorat Jenderal Perhubungan Darat, 1998).

\section{Tingkat Kepuasan Pengguna}

Mengetahui tingkat kepuasaan pengguna lahan parkir dapat dilakukan dengan penyebaran kuisioner kepada pengguna. Informasi yang ingin didapatkan peneliti dari pengguna parkir yaitu kemudahan manuver, kemudahan membuka pintu mobil, kondisi petak parkir terhadap kemudahan manuver, keberadaan petugas parkir terhadap kemudahan manuver, akses kondisi jalan, dan ramburambu dalam parkir. Berikut ini merupakan hasil yang diperoleh dari hasil penyebaran kuisioner 
tentang kepuasan pengguna lahan parkir: (1) kemudahan manuver (Gambar 5); (2) kemudahaan membuka pintu mobil (Gambar 6); kondisi petak parkir pada kemudahan manuver (Gambar 7); (4) keberadaan petugas parkir terhadap kemudahan manuver (Gambar 8); (5) akses kondisi jalan (Gambar 9); (6) rambu-rambu dalam parkir (Gambar 10).

\section{Kemudahan Manuver}

Gambar 5 memperlihatkan bahwa 39\% responden menyatakan bahwa petak parkir di gedung parkir Anggrek Binus University nyaman ditinjau dari kemudahan manuver dan $26 \%$ menyatakan petak parkir yang ada cukup nyaman dalam hal kemudahan manuver. Dari gambar tersebut dapat disimpulkan bahwa responden lebih ke arah nyaman dengan petak parkir yang ada, meskipun masih ada sekitar $22 \%$ yang menyatakan tidak nyaman.

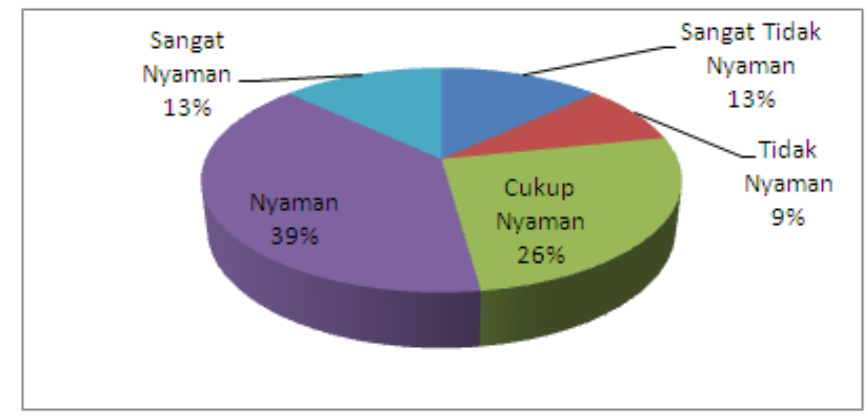

Gambar 5 Kemudahan manuver pada petak parkir

\section{Kemudahan Membuka Pintu Mobil}

Gambar 6 memperlihatkan bahwa 37\% responden menyatakan bahwa petak parkir gedung parkir Anggrek Binus University nyaman dalam hal kemudahan membuka pintu mobil. Akan tetapi, masih sekitar $24 \%$ menyatakan tidak nyaman dalam kemudahan membuka mobil di lokasi petak parkir.

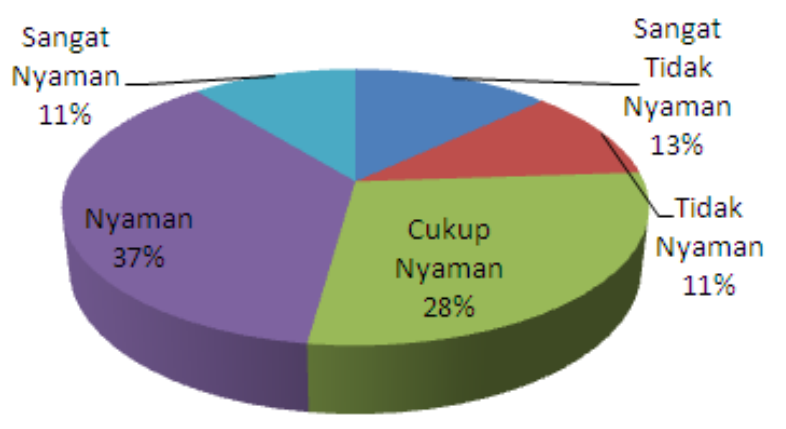

Gambar 6 Kemudahan membuka pintu mobil

\section{Kondisi Petak Parkir terhadap Kemudahan Manuver}

Gambar 7 memperlihatkan bahwa 26\% responden menyatakan kondisi petak parkir cukup berpengaruh bagi pengemudi dalam melakukan manuver. Kondisi petak yang dimaksud disini adalah keberadaan petak parkir (kosong/terisi mobil) disebelah kanan dan kiri dari petak yang akan digunakan untuk parkir. 


\section{Kondisi Sebelah Petak Parkir}

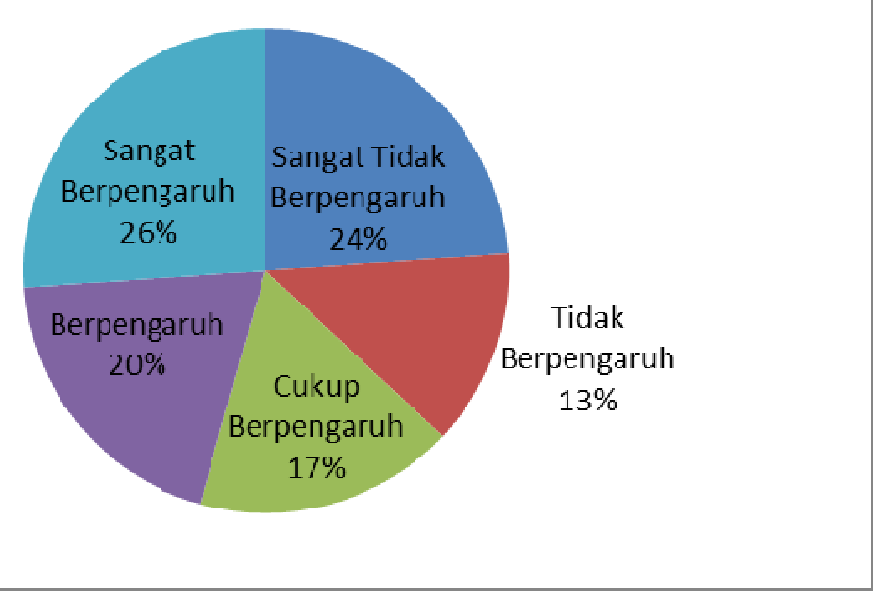

Gambar 7 Kondisi petak parkir terhadap kemudahan manuver.

\section{Keberadaan Petugas Parkir terhadap Kemudahan Manuver}

Gambar 8 memperlihatkan bahwa 30\% responden menyatakan bahwa keberadaan petugas parkir tidak membantu dan $26 \%$ yang lain menyatakan sangat tidak membantu pada saat penggguna melakukan manuver parkir di lapangan.

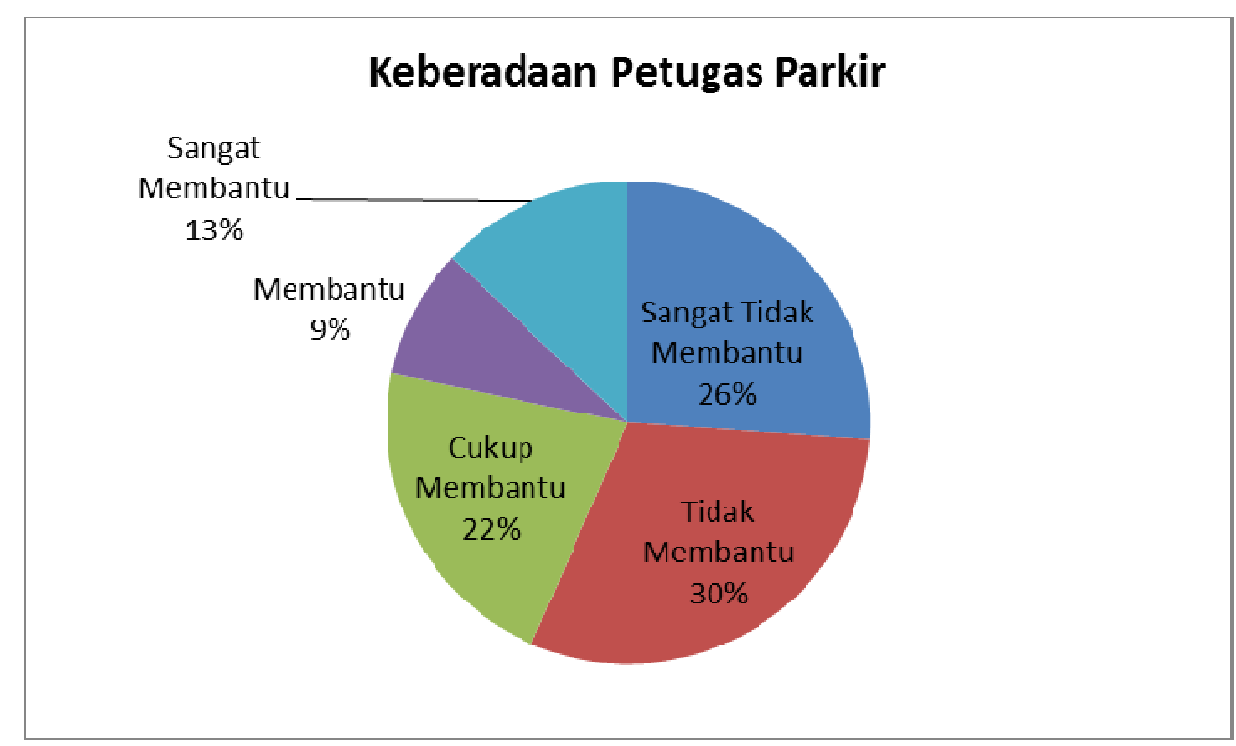

Gambar 8 Keberadaan petugas parkir terhadap kemudahan manuver

\section{Akses Kondisi Jalan}

Gambar 9 memperlihatkan bahwa $41 \%$ responden menyatakan cukup nyaman dengan kondisi jalan akses parkir, akan tetapi masih ada $20 \%$ menyatakan tidak nyaman dengan kondisi jalan parkir yang ada sekarang. 


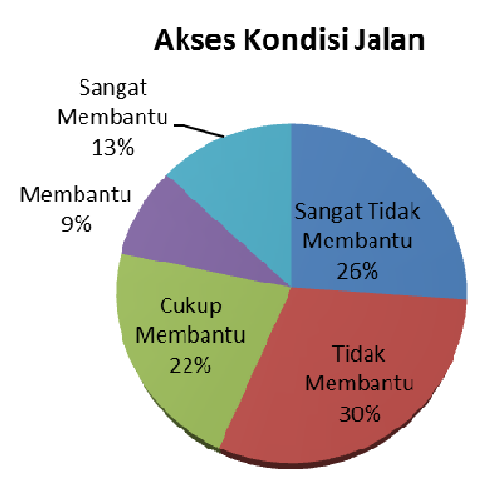

Gambar 9 Akses kondisi jalan

\section{Rambu-rambu dalam Parkir}

Gambar 10 memperlihatkan bahwa $24 \%$ responden menyatakan rambu-rambu dalam parkir membantu dalam menginformasikan arah lokasi parkir dan $41 \%$ menyatakan cukup membantu dalam menginformasikan arah lokasi parkir.

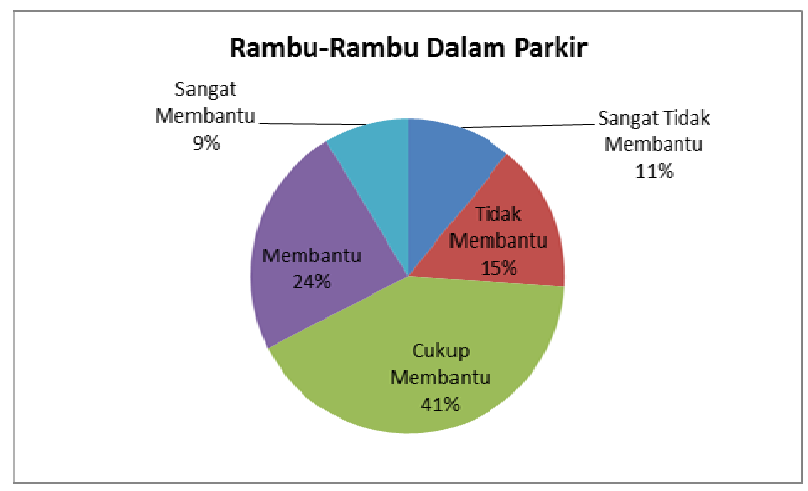

Gambar 10 Rambu-rambu dalam parkir

\section{PENUTUP}

Dari hasil penelitian kesimpulannya adalah diperoleh sebagai berikut: (1) petak parkir yang ada pada Kampus Anggrek Binus University terdiri dari dua dimensi ukuran petak parkir yaitu $4000 \mathrm{x}$ 2400mm di lokasi segmen 1, segmen 2, lantai 1 sampai dengan lantai 2 dan 5000 x 3000mm di lokasi segmen 3, segmen 4 dan segmen 5; (2) petak parkir dimensi 4000 x 2400mm, jenis kendaraan yang memenuhi persyaratan ruang bebas melakukan parkir arah lateral di petak tersebut adalah city car, jeep, dan MPV. Sedangkan untuk arah longitudinal di petak parkir dimensi 4000 x 2400mm, tidak satu pun jenis kendaraan memenuhi persyaratan ruang bebas parkir; (3) petak parkir dimensi $5000 \times 300 \mathrm{~m}$ $\mathrm{m}$, persyaratan ruang bebas parkir untuk arah lateral terpenuhi untuk semua jenis kendaraan. Sedangkan untuk arah longitudinalnya, hanya jenis kendaraan city car, jeep, dan MPV yang memenuhi persyaratan ruang beban kendaraan arah longitudinal; (4) pola parkir yang ada di lahan parkir Kampus Anggrek adalah parkir kendaraan satu sisi dan parkir kendaraan dua sisi, dimana kedua pola parkir tersebut membentuk sudut $90^{\circ}$. Keuntungan dari pola parker ini mempunyai daya tamping lebih banyak jika dibandingkan dengan pola parker paralel, tetapi kemudahan dan kenyamanan 
pengemudi melakukan maneuver masuk dan keluar ke ruangan parker lebih sedikit jika dibandingkan dengan pola parker dengan sudut yang lebih kecil dari $90^{\circ}$; (5) lebar jalur sirkulasi satu arah yang digunakan di semua area parkir anggrek. Keuntungan jalur sirkuasi satu arah ini adalah jarang atau sangat kecil terjadinya konflik (saling berbenturan antar mobil). Jalur sirkulasi yang ada pada lantai 1 sampai dengan lantai 8 adalah 7,5 m sedangkan batas aman dari lebar jalur sirkulasi adalah 3,5 m. Dari hasil ini dapat dikatakan bahwa jalur sirkulasi yang ada sudah memenuhi standar Pedoman Perencanaan dan Pengoperasian Fasilitas Parkir; (6) dalam hal kemudahan manuver parkir, 39\% responden menyatakan bahwa petak parkir di gedung parkir kampus anggrek nyaman dan $26 \%$ menyatakan petak parkir yang ada cukup nyaman dalam hal kemudahan manuver. Hasil ini menyimpulkan bahwa responden lebih ke arah nyaman dengan petak parkir yang ada, meskipun masih ada sekitar $22 \%$ yang menyatakan tidak nyaman. Salah satu ketidaknyaman ini bisa dilihat dari geometri pola parkir yang membentuk sudut $90^{\circ}$ memang memiliki tingkat kemudahan manuver parkir yang lebih rendah di banding dengan sudut yang lebih kecil dari $90^{\circ}$; (7) dalam hal kemudahan membuka pintu mobil, 37\% responden menyatakan bahwa petak parkir gedung parkir Anggrek Binus University nyaman. Akan tetapi, masih sekitar $24 \%$ menyatakan tidak nyaman dalam kemudahan membuka mobil di lokasi petak parkir. Kemudahan membuka pintu mobil ini berkorelasi dengan ruang bebas kendaraan arah lateral. Dari hasil pengukuran geometri, dinyatakan bahwa jenis kendaraan seperti sedan dan SUV memang tidak memenuhi standar ruang bebas kendaraan arah lateral. Jadi dapat di simpulkan bahwa $24 \%$ dari responden yang menyatakan tidak nyaman, secara umum merupakan responden yang menggunakan kedua jenis kendaraan tersebut; (8) dalam hal petugas parkir, 30\% responden menyatakan bahwa keberadaan petugas parkir tidak membantu dalam kegiatan manuver parkir dan $26 \%$ yang lain menyatakan sangat tidak membantu pada saat penggguna melakukan manuver parkir di lapangan; (9) rambu yang ada sudah baik yang dinyatakan bahwa $24 \%$ responden menyatakan rambu-rambu dalam parkir membantu dalam menginformasikan arah lokasi parkir dan $41 \%$ menyatakan cukup membantu dalam menginformasikan arah lokasi parkir. Adapun saran yang dapat dilakukan untuk penelitian berikutnya adalah sebagai berikut: (1) perlu adanya pendataan jenis kelamin dan kendaraan yang memarkir di petak-petak parkir yang di sediakan sehingga hasil kesimpulan dari data kuisioner lebih ke arah perilaku pengemudi dan jenis kendaraan; (2) perlunya penambahan petugas parkir sehingga membantu pengguna pada saat memarkirkan kendaraannya; (3) perlu adanya studi perbandingan kondisi pola sudut parkir $45^{\circ}, 60^{\circ}, 90^{\circ}$, untuk mengetahui tingkat pelayanan parkir dari sisi pengguna; (4) perlu dilakukan studi seberapa efektif penempatan alokasi petak parkir untuk jenis kendaraan tertentu mempengaruhi tingkat kenyamanan pengguna parkir.

\section{DAFTAR PUSTAKA}

Direktorat Jenderal Perhubungan Darat. (1998). Pedoman Perencanaan dan Pengoperasian Fasilitas Parkir. Jakarta: Direktorat Jenderal Perhubungan Darat.

Hidayat, Irpan. (2011). Studi parkir kampus anggrek kondisi eksisting dan penambahan lahan parkir baru terhadap pengguna kampus anggrek binus university. Comtech, 2 (2).

Papacostas, Prevedouros. (1993). Transportation Engineering \& Planning (2nd ed.). New Jersey: Prentice Hall.

Setiawan, Rudi. (2005). Studi Kelayakan Pembangunan Gedung Parkir dan Analisi "Willingness to Pay”: Studi Kasus di Universitas Kristen Petra.

Skripsi tidak diterbitkan. Universitas Kristen Petra, Surabaya 